\title{
Insight into Equilibrium and Kinetics of the Binding of Cadmium Ions on Radiation-Modified Straw from Oryza sativa
}

\author{
Sana Zulfiqar Ali, Makshoof Athar, Umar Farooq, and Muhammad Salman \\ Institute of Chemistry, University of the Punjab, Lahore 54590, Pakistan \\ Correspondence should be addressed to Umar Farooq; umar.chem@pu.edu.pk
}

Received 26 March 2013; Accepted 24 May 2013

Academic Editor: Luqman Chuah Abdullah

Copyright (C) 2013 Sana Zulfiqar Ali et al. This is an open access article distributed under the Creative Commons Attribution License, which permits unrestricted use, distribution, and reproduction in any medium, provided the original work is properly cited.

\begin{abstract}
The present study reports the chemical modification of agricultural waste (rice straw) with urea using microwave radiation and the efficiency evaluation of this modified rice straw for the adsorption of a toxic heavy metal, cadmium. The elemental analysis of urea modified rice straw affirmed urea grafting on rice straw, and FTIR spectra of chemically benign modified adsorbent showed the presence of hydroxyl, carbonyl, and amino functional groups. Effects of process parameters (adsorbent dosage, contact time, agitation speed, $\mathrm{pH}$, and temperature) were studied in batch mode. Parameters were optimized for the equilibrium study, and adsorption mechanism was elucidated using five mathematical models (Langmuir, Freundlich, Temkin, Harkin-Jura, and DubininRadushkevich). Binding of Cd(II) ions on modified adsorbent followed Langmuir model, and the maximum uptake capacity was found to be $20.70 \mathrm{mg} \mathrm{g}^{-1}$. Kinetic modeling was done using six different kinetic models. The process was considered physisorption according to the obtained activation energy value. Thermodynamic parameters confirmed the process to be favorable and feasible. Exothermic nature of adsorption of Cd(II) ions on urea modified rice straw was confirmed by the negative value of $\Delta H^{\circ}$.
\end{abstract}

\section{Introduction}

Rapid pace of industrialization has resulted in a number of problems among which water pollution is considered to be one of the serious problems. Industrial processes discharge huge amounts of untreated wastewater daily into the surrounding environment, leading to detrimental effects on aquatic, plant, and human life. Heavy metal such as lead, cadmium, chromium, and copper is regarded as major pollutants in wastewater. These contaminants are of major concern because they do not degrade naturally [1].

Cadmium has attracted wide attention of environmental chemists as one of the most toxic metals and has been categorized as a human carcinogen by USEPA (United States Environment Protection Agency), WHO (World Health Organization), and NTP (National Toxicology Program) [2]. It is a nonessential and nonbiodegradable metal which slowly accumulates in the human body, usually from food chain. The permissible limits for cadmium by WHO and USEPA are $3 \mu \mathrm{g} \mathrm{L} \mathrm{L}^{-1}$ and $5 \mu \mathrm{g} \mathrm{L}-1$, respectively. It affects lungs, liver, and pancreas and disturbs the human DNA repair system.
Chronic cadmium poisoning causes characteristic yellow pigmentation of teeth (the yellow ring of cadmium) [2].

It is important to treat contaminated waters on a continuous basis due to need of hour. A number of technologies are available with varying degree of success, and among them adsorption process is considered relatively better because of convenience, ease of operation, and simplicity of design [3]. Activated carbon has been utilized as the commercial adsorbent for the removal of pollutant from wastewater because of its excellent adsorption ability. However, its use is restricted due to high cost.

Recently, many nonconventional, low-cost adsorbents including natural materials, (biosorbents) and waste materials have been proposed by several researchers. Cadmium has been reported to be removed and recovered from aqueous solutions by a number of biosorbents [4-8]. Modification of the natural materials (biosorbents) has gained numerous cost-effective and efficient adsorbents for the uptake of pollutants from aqueous solution. Certain physical and chemical methods such as heating, freezing, drying, cross-linking with organic solvents, chemical reactions with a variety of 


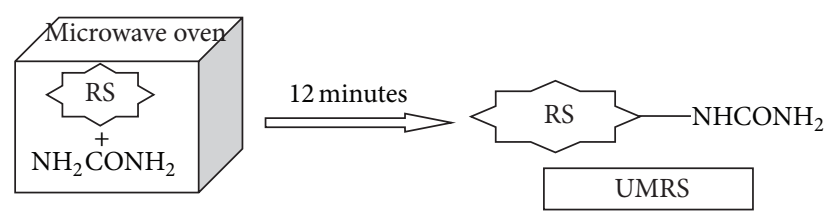

SCHEME 1

organic and inorganic compounds, and modification under microwave radiation in the absence of any solvent have been utilized in this regard [9-13]. The modifications produce adsorbents which have greater exposed metal-binding sites as compared to raw adsorbents. The chemically modified adsorbent offers a larger available surface area. The surface chemistry is altered after modification due to the incorporation of new functional groups by changing the already present functional groups on any adsorbent. These modified functional groups act as complexing or chelating agents for metals [14-16]. Modification with microwave radiation is advantageous because it is a simple process and does not require any solvent. Also no harmful vapors are added to the environment.

Rice (Oryza sativa) is one of the major crops grown throughout the world and is most important staple food for a large part of the world's human population. Rice straw, obtained as a byproduct of rice industry, is an agricultural waste which is used as a cost-effective adsorbent for a number of pollutants including metal ions. Rice straw is insoluble in water, has good chemical stability, and has high mechanical strength [17], making it good adsorbent material for treating heavy metals from wastewater.

The present study is based on the evaluation of effectiveness of a modified agricultural waste (rice straw) for the removal of toxic $\mathrm{Cd}$ (II) ions from aqueous solution in a batch process. Detailed equilibrium, kinetic, and thermodynamic studies elucidate the adsorption mechanism.

\section{Materials and Methods}

2.1. Collection and Urea Modification of Oryza sativa. Dried rice straw (Oryza sativa) was collected from the Punjab University area of Lahore, Pakistan. It was washed with water to remove the dust and particles and was air dried. Dried rice straw was grinded and sieved to pass 40-60 mesh (ASTM standard). It was again washed with water and dried in an oven at $105-110^{\circ} \mathrm{C}$ till constant mass. The dried biomass was mixed with urea (Merck, Germany) in 1:2 by mass and irradiated in a microwave oven (D131, Dawlance) for a period of 12 minutes. The procedure for modification is expressed in detail elsewhere [18] and shown in Scheme 1. This urea modified rice straw was designated as UMRS and stored in airtight plastic bottles for further use.

2.2. Characterization of UMRS. The prepared material UMRS was characterized using FTIR, elemental analysis, and surface area. In order to study the presence of potential functional groups in UMRS, the FTIR spectrum was scanned in $4000-400 \mathrm{~cm}^{-1}$ using standard method with the help of
FTIR spectrophotometer (Spectrum RX-1, Perkin Elmer). The elemental analysis was performed using elemental analyzer (EL III, Elementar, Vario) using corn gluten as a standard. The surface area was determined using Langmuir equilibrium model.

2.3. Batch-Stirred Biosorption Experiments. A concentration difference method was used to study the effect of various parameters on the biosorption of Cd(II) by UMRS. Cadmium (II) nitrate (Merck, Germany) was used to prepare the aqueous solution of Cd(II). Distilled water was used for all types of solution preparations and dilutions as per requirement. In all experiments, measuring/conical flasks $(100 \mathrm{~mL})$ were used containing $\mathrm{Cd}(\mathrm{II})$ solution $(50 \mathrm{mg} / \mathrm{L}, 50 \mathrm{~mL})$ of a known concentration at a specific $\mathrm{pH}$. A known amount of UMRS (0.2-1.4 g) was added to the solution and then agitated on an orbital shaker (OSM-747, Vortex) at predefined speed $(125 \mathrm{rpm})$. After a specific period of time, the contents were filtered, and the filtrate was analyzed using atomic absorption spectrophotometer (AAnalyst 100, Perkin Elmer) to determine the equilibrium $\mathrm{Cd}(\mathrm{II})$ ions concentrations. The difference of initial $\left(C_{0}, \mathrm{mg} \mathrm{L}^{-1}\right)$ and equilibrium $\left(C_{e}\right.$, $\mathrm{mg} \mathrm{L}^{-1}$ ) metal ion concentration was considered to be sorbed by UMRS. The removal (R\%) of $\mathrm{Cd}(\mathrm{II})$ and/or the amount of Cd(II) sorbed per unit mass of UMRS at equilibrium $\left(q_{e}\right.$, $\mathrm{mg} \mathrm{g}^{-1}$ ) were determined using the following formula:

$$
\begin{gathered}
R \%=\frac{C_{0}-C_{e}}{C_{0}} \times 100, \\
q_{e}=\frac{C_{0}-C_{e}}{m} \times v,
\end{gathered}
$$

where " $m$ " (g) is the mass of UMRS and " $v$ " (L) is the volume of Cd(II) solution used for the experiment.

The effects of parameters like time of contact, $\mathrm{pH}$, dose of UMRS, agitation speed, temperature, and concentration of $\mathrm{Cd}(\mathrm{II})$ ions on the biosorption process were studied in a similar way. Blank experiments were performed in order to study the adsorption of Cd(II) by the glassware. No detectable adsorption of Cd(II) was found by the glassware. All the graphs were prepared using Microsoft Excel 2003 software. Regression analyses have also been performed by calculating $R^{2}$ to investigate the suitability of certain mathematical model. Root mean square errors (RMSE) were calculated in order to evaluate the error of the model predictions. The sum of the squares of the difference between metal removal experimental data $\left(q_{\text {exp }}\right)$ and model predictions $\left(q_{\mathrm{cal}}\right)$ was divided by the number of data points $(N)$ for each data set, and the square root of this term was taken as follows:

$$
\mathrm{RMSE}=\sqrt{\frac{\sum\left(q_{\exp }-q_{\mathrm{cal}}\right)^{2}}{N} .}
$$

\section{Results and Discussion}

3.1. Effect of $p H$. The $\mathrm{pH}$ of the solution is probably the most important parameter as it affects the charges on biomass as 


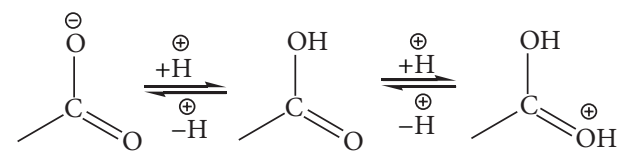

SCHEME 2

well as metal speciation in the solution. The metal species are influenced by the solution $\mathrm{pH}$. Cadmium ions are present as free $\mathrm{Cd}^{2+}$ species along the whole acidic $\mathrm{pH}$ range. As the $\mathrm{pH}$ is increased above $\mathrm{pH} 7.5$, it starts to precipitate as $\mathrm{Cd}(\mathrm{OH})_{2}$, and thus it is no more "available" for biosorption. This narrows down the upper $\mathrm{pH}$ limit for the biosorption of $\mathrm{Cd}(\mathrm{II})$ by UMRS. So, during the study of the effect of $\mathrm{pH}$, the range that should be scanned for the optimum $\mathrm{pH}$ is limited to an upper value of 7.5 [16].

On the other hand, in highly acidic $\mathrm{pH}$, there are a greater number of $\mathrm{H}^{+}$ions present in the solution. These $\mathrm{H}^{+}$ions are readily sorbed on the sites of the biomass (UMRS) and thus protonate it before metal ions can attack these sites. This causes UMRS to behave as positive specie. Due to the electrostatic repulsive force present between two positive species, a limited number of Cd(II) ions are sorbed on UMRS, and thus there should be low $q_{e}$ value at low $\mathrm{pHs}$. When the $\mathrm{pH}$ is raised from highly acidic $\mathrm{pH}$, this positive character decreases. UMRS, being a modified lignocellulosic material, contains a variety of functional groups including carbonyl, amide, hydroxyl, and thiol. The behavior of each of these functional groups changes with the change in solution $\mathrm{pH}$. For example, carboxyl groups are protonated in highly acidic $\mathrm{pHs}$ ( $\mathrm{pH}$ less than 3 ) acting as positively charged species and attracting negative charged ions [19]. On increasing the $\mathrm{pH}$, the deprotonation (ionization) of these functional groups causes them to act as negative moieties. At this stage, they attract and attach positive cations like $\mathrm{Cd}(\mathrm{II})$ ions more readily. It may be represented as shown in Scheme 2 [16].

The protonation and deprotonation of other available functional groups can be explained on similar grounds. It can be predicted that at highly acidic pHs, Cd(II) binding with UMRS is reduced, and the binding increases with increase in $\mathrm{pH}$ because UMRS is negatively charged. This effect of $\mathrm{pH}$ of solution on biomass, thus, decides the lower limit of $\mathrm{pH}$. Based on the previous discussion, the effect of $\mathrm{pH}$ was studied in $\mathrm{pH}$ range of 2-7.

The $\mathrm{pH}$ profile study is shown in Figure 1. It is obvious that the binding of $\mathrm{Cd}(\mathrm{II})$ by UMRS increased with increase in $\mathrm{pH}$. This is in conformity with the previous discussion. No significant change in the $q_{e}$ value is observed as the $\mathrm{pH}$ is increased above 5. This indicated that the $\mathrm{pH}$ had a vital role in the biosorption of Cd(II) by UMRS and the maximum binding occurred at a $\mathrm{pH}$ of 5 . A number of studies, in the literature, on the biosorptive removal of $\mathrm{Cd}(\mathrm{II})$ by various biosorbents reported the optimum $\mathrm{pH}$ between 5-6 [18, 2022]. Almost similar values of $\mathrm{pH}$ indicate that the biosorption of $\mathrm{Cd}(\mathrm{II})$ ions seems not to be dependent on the biosorbent material. The material only provides the lower $\mathrm{pH}$ limit for biosorption of Cd(II) ions.

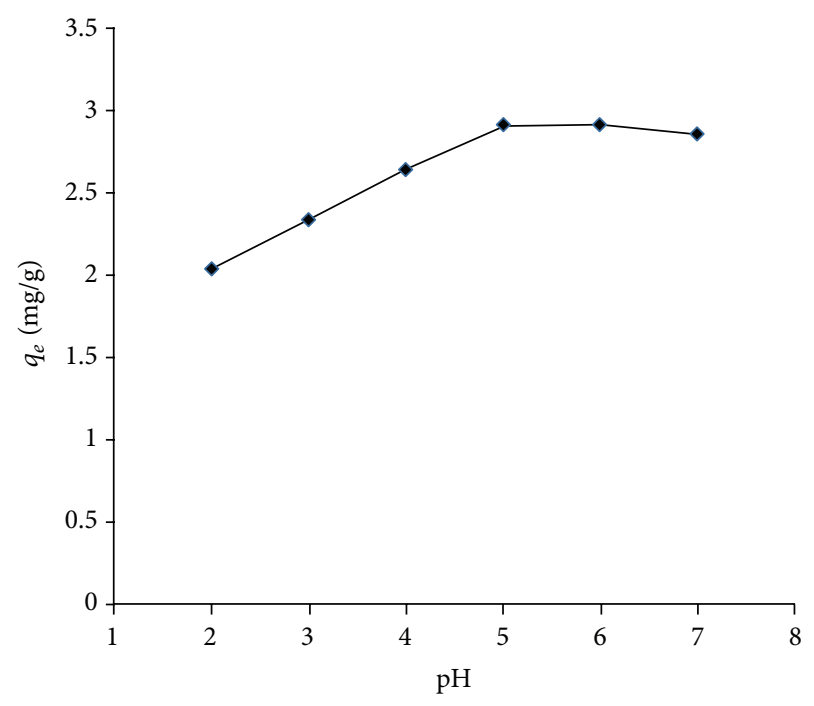

FIGURE 1: Effect of change in $\mathrm{pH}$ on biosorption of Cd(II) on UMRS $\left(C_{0}=50 \mathrm{mg} / \mathrm{L}\right.$, time $\left.=10 \mathrm{~min}\right)$.

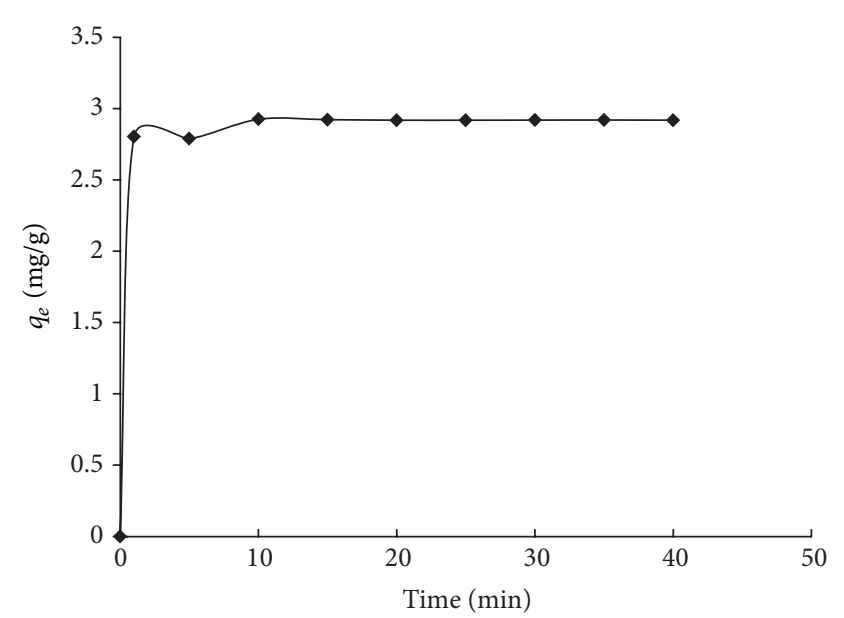

FIGURE 2: Effect of contact time on Cd(II) biosorption by UMRS $\left(C_{0}=50 \mathrm{mg} / \mathrm{L}\right)$.

3.2. Effect of Contact Time-Biosorption kinetics. The contact time studies are very critical as these endow with the minimum time required to remove maximum amount of $\mathrm{Cd}(\mathrm{II})$ ions from the solution and thus help in scaling up the process. The optimum (equilibrium) time helps in studying the rate of biosorption process. With the help of kinetic data, the rate determining step of the transport mechanism and thus the modeling and design of the process can be described.

The effect of contact time on the removal of Cd(II) by UMRS is depicted in Figure 2. It was observed that by increasing the time of contact, the metal removal $\left(q_{e}\right)$ increased rapidly. This continued till the $q_{e}$ achieved a maximum value at a time of contact of 10 minutes. The rapid increase in the $q_{e}$ values in the initial 10 minutes can be attributed to a greater number of binding sites available during initial stages. This indicated the physical binding of Cd(II) ions with UMRS [18]. As time proceeded, the number of binding sites was reduced due to accumulation of $\mathrm{Cd}(\mathrm{II})$ ions on the UMRS leading 
TABLE 1: Kinetics of the biosorption of Cd(II) onto UMRS.

\begin{tabular}{|c|c|c|c|c|}
\hline Model & Linear equation & $q_{e \exp }\left(\mathrm{mgg}^{-1}\right)$ & Model p & \\
\hline Elovich model & $q_{t}=\frac{\ln (a \times b)}{b}+\frac{\ln t}{b}$ & \multirow{6}{*}{2.924} & $\begin{array}{c}a\left(\mathrm{mg} \mathrm{g}^{-1} \mathrm{~min}^{-1}\right) \\
b\left(\mathrm{~g} \mathrm{mg}^{-1}\right) \\
R^{2}\end{array}$ & $\begin{array}{c}4.62 \times 10^{29} \\
25.64 \\
0.6931\end{array}$ \\
\hline First order & $\frac{1}{q_{t}}=\frac{1}{q_{e}}+\frac{k_{1}}{q_{e} t}$ & & $\begin{array}{c}k_{1}\left(\min ^{-1}\right) \\
q_{e \text { calc }}\left(\mathrm{mgg}^{-1}\right) \\
R^{2}\end{array}$ & $\begin{array}{c}0.0452 \\
2.914 \\
0.5245\end{array}$ \\
\hline Pseudo-first order & $\ln \left(q_{e}-q_{t}\right)=\ln q_{e}-k_{1} t$ & & $\begin{array}{c}k_{1}\left(\min ^{-1}\right) \\
q_{e \text { calc }}\left(\mathrm{mg} \mathrm{g}^{-1}\right) \\
R^{2}\end{array}$ & $\begin{array}{l}0.1074 \\
0.1537 \\
0.4734\end{array}$ \\
\hline Second order & $\frac{1}{C_{e}}-\frac{1}{C_{0}}=k_{2} t$ & & $k_{2}\left(\mathrm{~g} \mathrm{mg}^{-1} \mathrm{~min}^{-1}\right)$ & $\begin{array}{l}0.0026 \\
0.4644\end{array}$ \\
\hline Pseudo-second order & $\frac{t}{q_{t}}=\frac{1}{k_{2} q_{e}^{2}}+\frac{t}{q_{e}}$ & & $\begin{array}{c}k_{2}\left(\mathrm{~g} \mathrm{mg}^{-1} \mathrm{~min}^{-1}\right) \\
q_{e \text { calc }}\left(\mathrm{mg} \mathrm{g}^{-1}\right) \\
R^{2}\end{array}$ & $\begin{array}{l}4.6812 \\
2.929 \\
0.999\end{array}$ \\
\hline Intraparticle diffusion & $q_{t}=k_{\mathrm{WM}} \sqrt{t}+C$ & & $\begin{array}{c}k_{\mathrm{WM}}\left(\mathrm{mg} \mathrm{g}^{-1} \min ^{-1 / 2}\right) \\
R^{2}\end{array}$ & $\begin{array}{l}0.0245 \\
2.7902 \\
0.6166\end{array}$ \\
\hline
\end{tabular}

to the decrease in the binding of metal ions. Thus the rate of biosorption decreases in the later stages. After a contact time of 10 minutes, the graph becomes virtually parallel to the time axis, indicating the establishment of the equilibrium. Thus 10 minutes were taken as the optimum time of contact for the biosorption of Cd(II) onto UMRS. This equilibrium (optimum) time is found shorter than a number of studies reported in the literature for the biosorption of $\mathrm{Cd}(\mathrm{II})$ ions onto various biosorbents [18, 20-22].

The reaction kinetics was investigated by using a number of different available kinetic models. The experimental data obtained from the contact time studies was used for the purpose. The linear forms of the Elovich, first-order, pseudofirst-order, second-order, and pseudo-second-order kinetic models [23-27] are, respectively, given as

$$
\begin{gathered}
q_{t}=\frac{\ln (a \times b)}{b} \times \frac{\ln t}{b}, \\
\frac{1}{q_{t}}=\frac{1}{q_{e}}+\frac{k_{1}}{q_{e} t}, \\
\ln \left(q_{e}-q_{t}\right)=\ln q_{e}-k_{1} t, \\
\frac{1}{C_{e}}-\frac{1}{C_{0}}=k_{2} t, \\
\frac{t}{q_{t}}=\frac{1}{k_{2} q_{e}^{2}}+\frac{t}{q_{e}},
\end{gathered}
$$

where $a\left(\mathrm{mg} \mathrm{g}^{-1} \mathrm{~min}^{-1}\right)$ gives the rate constant and $b\left(\mathrm{~g} \mathrm{mg}^{-1}\right)$ gives rate of adsorption at zero coverage in Elovich model. $k_{1}\left(\min ^{-1}\right)$ is the first-order rate constant, $q_{e}$ and $q_{t}$ are the amounts of metal ions sorbed per gram of biomass $\left(\mathrm{mg} \mathrm{g}^{-1}\right)$ at equilibrium and at time " $t$," respectively, and $k_{2}\left(\mathrm{mg} \mathrm{g}^{-1} \mathrm{~min}^{-1}\right)$ is the second-order rate constant. The parameters for the kinetic models were determined from respective plots (Figure 3 ) and are given in Table 1 .
The experimental data were used to study the kinetics of the process using Elovich model (Figure 3(a)). The value of coefficient of determination $\left(R^{2}=0.6931\right)$ is quite less than 0.98 . This low value indicated that the kinetics of $\mathrm{Cd}(\mathrm{II})$ biosorption by UMRS could not be discussed based on the Elovich model. In other way, Cd(II)-UMRS biosorption system did not follow Elovich kinetic model. The literature shows that Elovich model is the least applied kinetic model to biosorption systems, and only a few examples show the application of this model over the whole kinetic data [28, 29].

The plots for first-order and pseudo-first-order kinetic models are shown in Figures 3(b) and 3(c). The comparison of the experimental and calculated $q_{e}$ values provides a tool for deciding the fitting of the model over the experimental data. As shown in Table 1, it can be observed that the calculated $q_{e}$ $\left(2.914 \mathrm{mg} \mathrm{g}^{-1}\right)$ value for the first-order model is comparable with the experimental value $\left(2.924 \mathrm{mg} \mathrm{g}^{-1}\right)$. This pointed to the possible fitting of the model for the process. The value of the first-order rate constant $k_{1}$ is $0.0452\left(\mathrm{~min}^{-1}\right)$. However, $R^{2}(0.5245)$ is quite less than 0.98 . So, it can be inferred that first-order model cannot be applied to explain the biosorption process under study. On the other hand, the calculated $q_{e}\left(0.1537 \mathrm{mg} \mathrm{g}^{-1}\right)$ value for pseudo-first-order model is significantly different from the experimental $q_{e}$ $\left(2.924 \mathrm{mg} \mathrm{g}^{-1}\right)$ value. The value of the pseudo-first-order rate constant $k_{1}$ is $0.1074\left(\mathrm{~min}^{-1}\right)$. In addition, $R^{2}$ value $(0.4734)$ is quite less than 0.98 . Hence it can be concluded that $\mathrm{Cd}(\mathrm{II})$ UMRS biosorption system did not follow the pseudo-firstorder kinetic model. This observation is in accordance with the studies reported in the literature for the fitting of firstorder and pseudo-first-order kinetic models (Table 2).

The plots for second-order $\left(t\right.$ versus $\left.1 / C_{e}-1 / C_{0}\right)$ and pseudo-second-order ( $t$ versus $\left.t / q_{t}\right)$ kinetic models are given in Figures 3(d) and 3(e). The value of second-order rate constant $k_{2}$ was quite low $\left(0.0026 \mathrm{~g} \mathrm{mg}^{-1} \mathrm{~min}^{-1}\right)$. The $R^{2}$ value for the second-order kinetic model (0.4644) indicted that this 


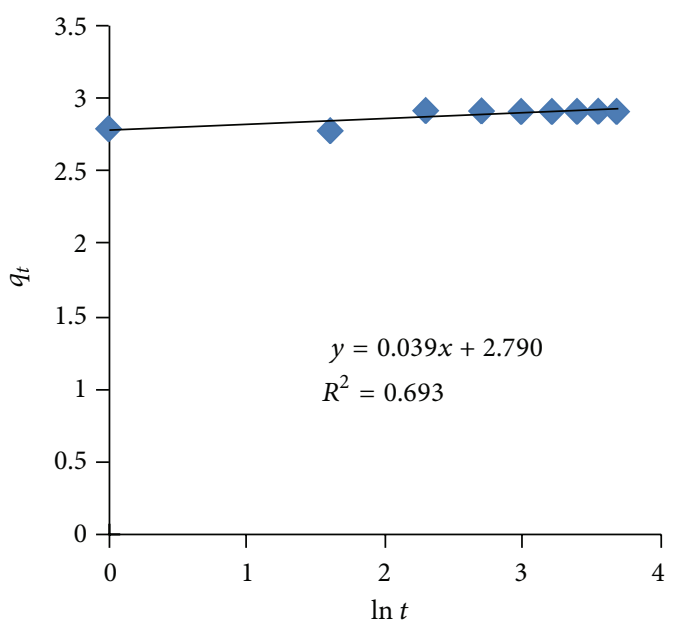

(a)

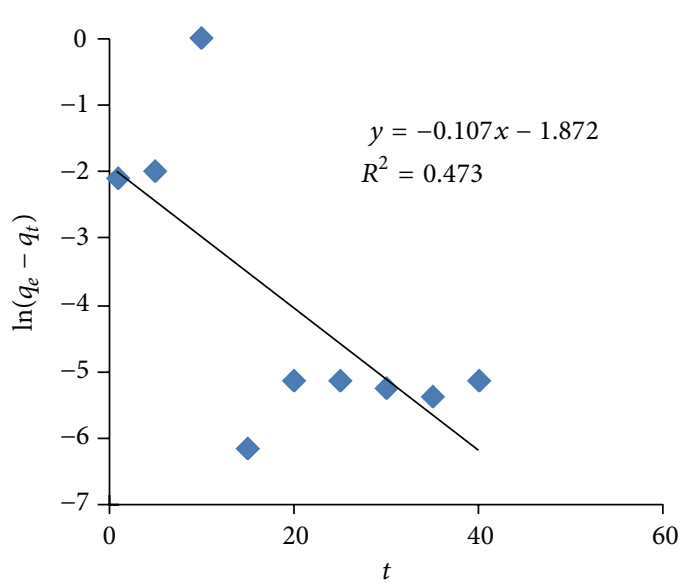

(c)

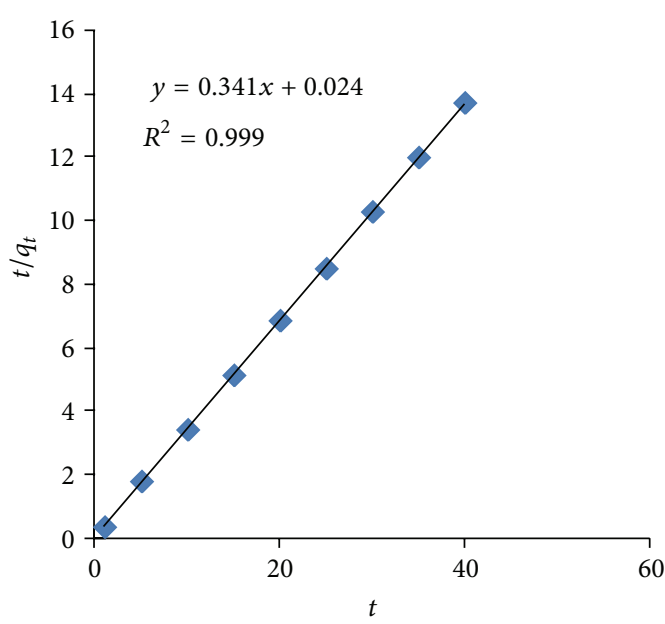

(e)

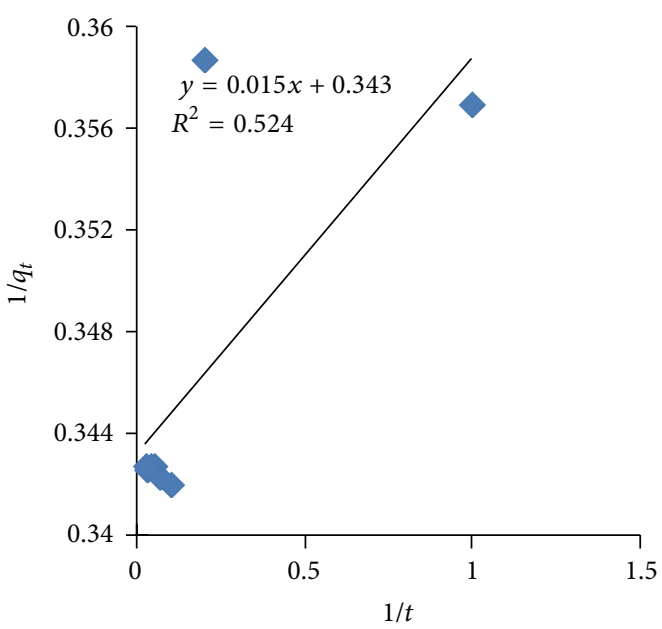

(b)

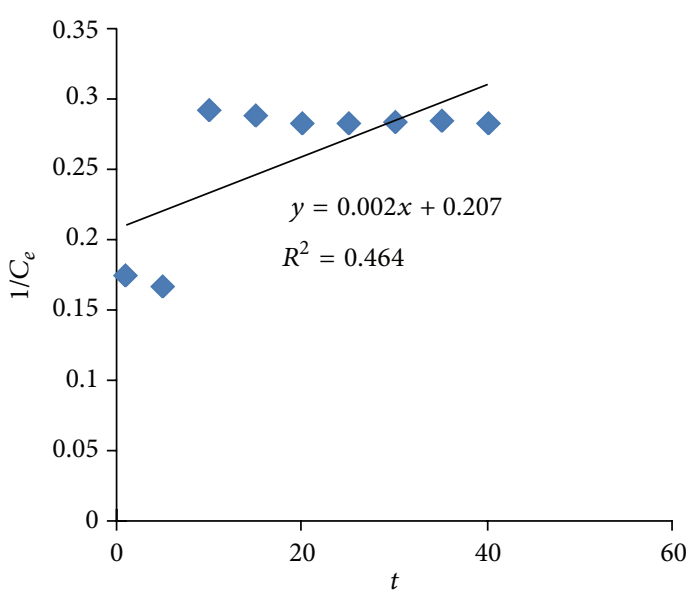

(d)

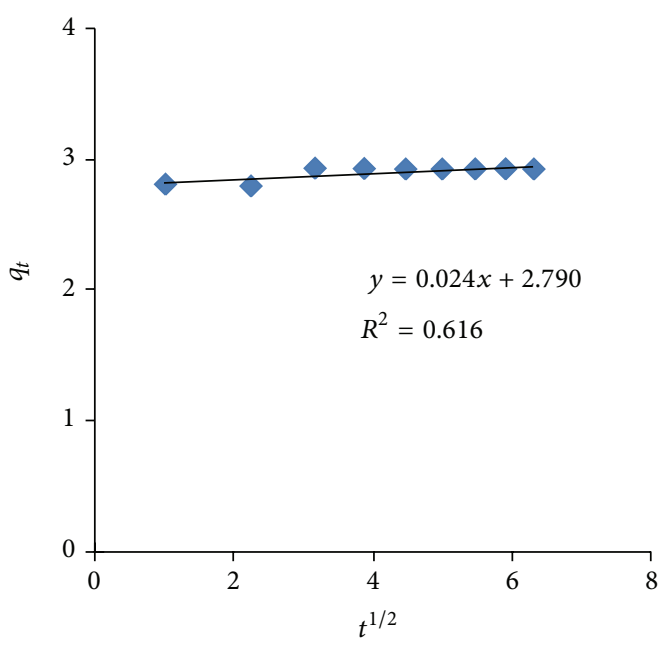

(f)

FIGURE 3: Kinetic models for the binding of Cd(II) onto UMRS (a) Elovich, (b) first-order, (c) pseudo-first-order, (d) second-order, (e) pseudo-second-order, and (f) intraparticle diffusion models. 
TABLE 2: Comparison of capacity of UMRS with some other reported biosorbents.

\begin{tabular}{|c|c|c|c|c|}
\hline Biomass & Biosorption capacity $\left(q_{m}, \mathrm{mg} \mathrm{g}^{-1}\right)$ & Equilibrium model $^{\mathrm{a}}$ & Kinetic model $^{\mathrm{b}}$ & Reference \\
\hline Sulfonated Juniperus monosperma wood & 1.68 & - & PSO & {$[42]$} \\
\hline Juniperus monosperma & 2.80 & - & PSO & {$[42]$} \\
\hline Zea mays & 3.61 & & - & [43] \\
\hline Coconut copra meal & 4.92 & $\mathrm{~L}, \mathrm{RP}$ & - & {$[44]$} \\
\hline Nauclea diderrichii & 6.30 & $\mathrm{~L}$ & PSO & {$[45]$} \\
\hline Triticum aestivum (straw) & 11.56 & $\mathrm{~L}$ & - & {$[21]$} \\
\hline Triticum aestivum (straw) & 14.56 & $\mathrm{~L}$ & PSO & {$[40]$} \\
\hline Water Hyacinth & 14.67 & - & PSO & {$[46]$} \\
\hline Papaya wood & 17.22 & $\mathrm{~L}$ & PSO & {$[47]$} \\
\hline Spent grain & 17.30 & $\mathrm{~L}$ & - & {$[6]$} \\
\hline Urea modified Oryza sativa & 20.70 & $\mathrm{~L}$ & PSO & Present work \\
\hline Rhizopus cohnii & 40.50 & $\mathrm{~L}$ & - & {$[48]$} \\
\hline
\end{tabular}

${ }^{\mathrm{a}} \mathrm{L}$ : Langmuir model; RP: Redlich-Peterson model.

${ }^{b}$ PSO: pseudo-second-order model.

model cannot be applied to investigate the kinetics of Cd(II)UMRS biosorption system.

When the experimental data was used to draw the graph for pseudo-second-order kinetic model, straight plot for the whole set of data was observed. The comparison of calculated $q_{e}\left(2.929 \mathrm{mg} \mathrm{g}^{-1}\right)$ and experimental $q_{e}\left(2.924 \mathrm{mg} \mathrm{g}^{-1}\right)$ values showed that the difference between the two was too small to be significant. This indicated the possible fitting of the kinetic model for the process. The coefficient of determination $\left(R^{2}=\right.$ $0.9999)$ pointed to that the pseudo-second-order kinetic model could be used for the investigation of kinetics of the Cd(II) biosorption by UMRS.

It was found that Elovich, first-order, pseudo-first-order, and second-order models failed to explain the kinetics of $\mathrm{Cd}(\mathrm{II})$ biosorption by UMRS. In some cases, the experimental and calculated $q_{e}$ values were in close proximity; yet the coefficient of determination was opposing the fitting of the model (first-order model). Pseudo-second-order kinetic model was the best model, showing fitting over the whole set of experimental kinetic data. Hence, it can be concluded that pseudo-second-order model was suitable to explain the kinetics of the system under study, that is, Cd(II)-UMRS biosorption system. A number of authors have studied the biosorption of divalent metal ions onto various biosorbents and reported that such studies mostly followed pseudosecond-order kinetics (Table 2).

In order to have an insight into the rate determining step, Weber and Morris model, that is, intraparticle diffusion (IPD) model, was employed [30]. The linear form is shown as follows: (2f);

$$
q_{t}=k_{\mathrm{WM}} \sqrt{t}
$$

where $k_{\mathrm{WM}}$ is the intraparticle diffusion rate constant $\left(\mathrm{mgg}^{-1} \mathrm{~min}^{-1 / 2}\right)$. A straight line passing through the origin in $q_{t}$ versus $t^{1 / 2}$ plot will indicate that the sorption process is governed by intraparticle diffusion; that is, intraparticle diffusion is the rate determining step; otherwise boundary layer diffusion is the rate controlling step.
As shown in Figure 3(f), the varying extent of the binding of Cd(II) during initial and final stages of the experiment led to a plot virtually parallel to time axis. As the curve did not start from the origin (the intercept is not zero), so it can be inferred that intraparticle diffusion did not play a role in the rate determining step. So, boundary layer diffusion was the rate determining step, and the biosorption of $\mathrm{Cd}(\mathrm{II})$ by UMRS was governed by boundary layer diffusion. The value of $k_{\mathrm{WM}}$ is shown in Table 1. However, further studies are required to establish this observation.

3.3. Effect of Concentration-Equilibrium Modeling. The role of adsorption in the biosorption of Cd(II) ions by UMRS can be explained by the use of equilibrium modeling. The adsorption models indicate how Cd(II) ions distribute between the liquid and solid phases at equilibrium. A number of different models have been employed for the purpose in the present study. These models, namely, Langmuir equation (3a) [31], Freundlich equation (3b) [32], Temkin equation (3c) [33], Harkin-Jura equation (3d) [34], and Dubinin-Radushkevich equation (3e) [35], are given as, respectively,

$$
\begin{gathered}
q_{e}=\frac{q_{m} K_{L} C_{e}}{1+K_{L} C_{e}}, \\
q_{e}=K_{F} C_{e}^{1 / n}, \\
q_{e}=\frac{R T}{b} \ln \left(A_{T} C_{e}\right), \\
q_{e}=\left(\frac{A}{B-\log C_{e}}\right)^{1 / 2}, \\
q_{e}=q_{m} \exp \left(-\beta \varepsilon^{2}\right),
\end{gathered}
$$

where $K_{L}, K_{F}, 1 / n, A_{T}, b, A, B, \beta$, and $\varepsilon$ are the constants of these models.

Experimental data for the biosorption of Cd(II) ions by UMRS is plotted as $C_{e}$ versus $q_{e}$ graph (Figure 4 ). The fitting 
TABle 3: Equilibrium models studied at $303 \mathrm{~K}$.

\begin{tabular}{|c|c|c|c|}
\hline Model & Equation & & \\
\hline Langmuir & $q_{e}=\frac{q_{m} K_{L} C_{e}}{1+K_{L} C_{e}}$ & $\begin{array}{c}q_{m}\left(\mathrm{mg} \mathrm{g}^{-1}\right) \\
K_{L}\left(\mathrm{~L} \mathrm{mg}^{-1}\right) \\
R_{L} \\
R^{2} \\
\text { RMSE }\end{array}$ & $\begin{array}{c}20.70 \\
0.0409 \\
0.7576-0.2381 \\
0.9855 \\
0.65\end{array}$ \\
\hline Freundlich & $q_{e}=K_{F} C_{e}^{1 / n}$ & $\begin{array}{c}K_{F}\left(\mathrm{mg} \mathrm{g}^{-1}\right) \\
n \\
R^{2} \\
\text { RMSE }\end{array}$ & $\begin{array}{c}1.2018 \\
1.6575 \\
0.9128 \\
1.22 \\
\end{array}$ \\
\hline Temkin & $q_{e}=\frac{R T}{b} \ln \left(A_{T} C_{e}\right)$ & $\begin{array}{c}K_{T}\left(\mathrm{~L} \mathrm{mg}^{-1}\right) \\
B\left(R T / b, \mathrm{~kJ} \mathrm{~mol}^{-1}\right) \\
R^{2} \\
\text { RMSE }\end{array}$ & $\begin{array}{c}1.9022 \\
2.1612 \\
0.974 \\
0.30\end{array}$ \\
\hline Harkin-Jura & $q_{e}=\left(\frac{A}{B-\log C_{e}}\right)^{1 / 2}$ & $\begin{array}{c}A \\
B \\
R^{2} \\
\text { RMSE } \\
\end{array}$ & $\begin{array}{c}2.4606 \\
1.1722 \\
0.6002 \\
1.14 \\
\end{array}$ \\
\hline D-R & $q_{e}=q_{m} \exp \left(-\beta \varepsilon^{2}\right)$ & $\begin{array}{c}q_{m}\left(\mathrm{mg} \mathrm{g}^{-1}\right) \\
\beta \\
E\left(\mathrm{~kJ} \mathrm{~mol}^{-1}\right) \\
R^{2} \\
\text { RMSE }\end{array}$ & $\begin{array}{c}5.8532 \\
1 \times 10^{-6} \\
0.707 \\
0.814 \\
0.97\end{array}$ \\
\hline
\end{tabular}

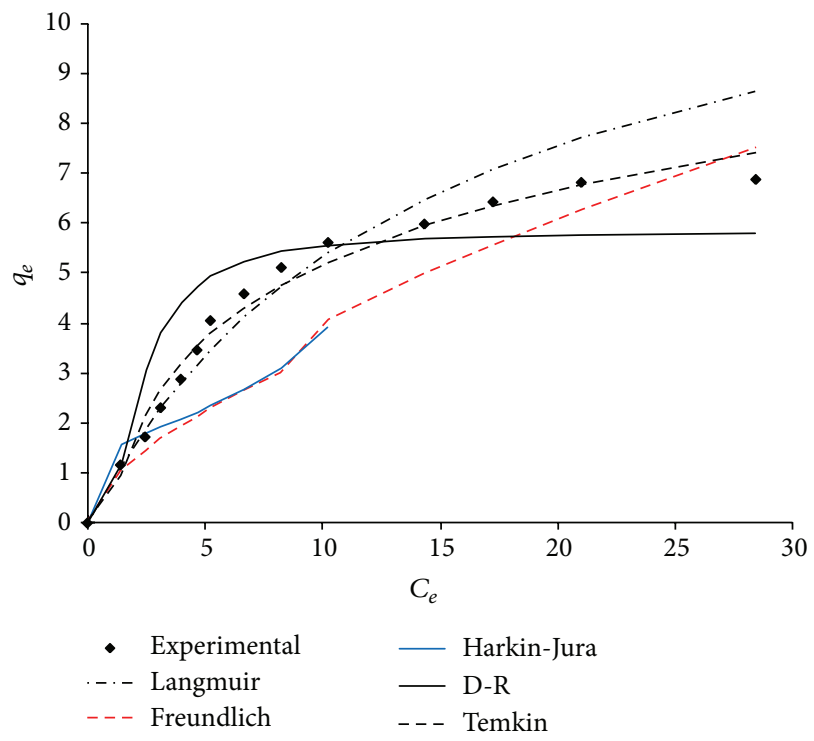

FIgURE 4: Equilibrium modeling of Cd(II) biosorption on UMRS.

of the equilibrium models is also represented on the same plot. The values of different equilibrium parameters and $R^{2}$ values have been determined with the help of these plots and are shown in Table 3.

The Langmuir model is one of the most frequently used equilibrium models and is employed to determine the maximum capacity of the biosorbent to bind the metal ions. It assumes that the uptake/binding of $\mathrm{Cd}(\mathrm{II})$ ions occurs on the homogenous surface by monolayer adsorption without any interaction between adsorbed ions. The nonlinear form of Langmuir model is used to explain the behavior of the Cd(II)-UMRS biosorption process. It can be observed that the Langmuir equilibrium curve significantly overlaps the experimental data (Figure 4). The $R^{2}$ value that is 0.9878 (greater than 0.98) points to the inference that the Langmuir model can explain the equilibrium of the biosorption process under study. The biosorption capacity of UMRS $\left(q_{m}\right)$ was found to be $20.7 \mathrm{mg} \mathrm{g}^{-1}$, and the adsorption constant $K_{L}$ was found to be $0.0409 \mathrm{~L} \mathrm{mg}^{-1}$.

The $q_{m}$ value thus calculated was used to determine the specific surface area $\left(S_{L}, \mathrm{~m}^{2} \mathrm{~g}^{-1}\right)$ of the material (UMRS) by using the following mathematical relationship:

$$
S_{L}=\frac{N_{A} A q_{m}}{M},
$$

where $N_{A}$ is Avogadro number $\left(6.02 \times 10^{23}\right), A$ refers to cross sectional area of metal ion $\left(\AA^{2}\right)$, and $M$ is the atomic mass of the metal ion. The specific surface area is calculated on the basis of the $q_{m}$ value, and it shows the surface area per gram of the material occupied by the metal ions. The atomic mass of cadmium is 112, and the cross sectional area is $3.73 \AA^{2}$ (the radius of $\mathrm{Cd}(\mathrm{II})$ ions for close packed monolayer is $1.09 \AA$ [18]). The specific surface area of UMRS for Cd(II) biosorption was found to be $4.15 \mathrm{~m}^{2} \mathrm{~g}^{-1}$.

The feasibility of Langmuir model is usually expressed by a dimensionless constant separation factor or equilibrium parameter $R_{L}$, defined as

$$
R_{L}=\frac{1}{1+K_{L} C_{0}},
$$

where " $K_{L}$ " is the Langmuir constant. The value of $R_{L}$ indicates the type of isotherm as unfavorable $\left(R_{L}>1\right)$, linear 
$\left(R_{L}=1\right)$, irreversible $\left(R_{L}=0\right)$, or favorable $\left(0<R_{L}<1\right)$ [36]. The $R_{L}$ values were calculated to lie in $0.7576-0.2381$. As these values lie between 0 and 1 , it can be deduced that the adsorption of $\mathrm{Cd}$ (II) ions onto UMRS is favorable under the studied conditions.

The Freundlich model assumes the nonzero interactions between the adsorbate particles and is based on multilayer adsorption on heterogeneous surface. The nonlinear plot for the model is shown in Figure 4. The comparison of the curve for the Freundlich model with the experimental data shows that this model can explain the biosorption of Cd(II) ions for the initial set of data only. The coefficient of determination $\left(R^{2}=0.9867\right)$ for initial range also supports the observation. The $1 / n$ value is less than 1 , and it shows that the sorption of metal ions is favorable on UMRS. As the Freundlich model states that the adsorption is exclusively physical one $[18,37]$, so it can be inferred that Cd(II) ions are sorbed physically on the heterogeneous surface (of UMRS) forming a layers having nonzero interactions between them.

Temkin model provides information about the heat of adsorption and the adsorbent-adsorbate interaction on the surfaces. Harkin-Jura model indicates the multilayer adsorption. The parameters for the both equilibrium models are shown in Table 3, and the fitting with the experimental data is represented in Figure 4. It can be observed that both the models do not fit with the experimental data, although data seemed to follow Temkin model at the later ends $\left(C_{e}>\right.$ $14 \mathrm{mg} \mathrm{L}^{-1}$ ). Although certain information about the nature of sorption are achieved yet due to disagreement of the experimental data with the models, these information/models are not suitable to explain the process, and further studies are required to establish the facts. However, $B_{T}$ value (less than 8 ) indicated low heat of adsorption and very weak interaction suggesting the process to be physisorption [38,39].

The physical or chemical nature of biosorption of $\mathrm{Cd}(\mathrm{II})$ onto UMRS can be assessed by determining the energy of sorption $(E)$ using the following equation:

$$
E=\frac{1}{\sqrt{2 \beta}}
$$

where $\beta$ is a coefficient related to the mean free energy of adsorption $\left(\mathrm{mol}^{2} \mathrm{~J}^{-2}\right)$. The value of $\beta$ can be determined using the Dubinin-Radushkevich (D-R) model. The adsorption process will be a physical adsorption for $E<8 \mathrm{~kJ} \mathrm{~mol}^{-1}$, and it will be chemisorption for $8<E<16 \mathrm{~kJ} \mathrm{~mol}^{-1}$ [40]. The value of energy $(E)$ was found to be less than $0.71 \mathrm{~kJ} \mathrm{~mol}^{-1}$, and thus the sorption of $\mathrm{Cd}$ (II) by UMRS was physical in nature. This is in accordance with the inference obtained from the Temkin model. Figure 4 shows that D-R model is not being followed by the Cd(II)-UMRS biosorption system. $R^{2}$ value is quite less than 0.98 . Hence, the values of Polanyi potential $(\varepsilon), \beta$ and the energy of sorption $(E)$ were determined without significant accuracy. As the systems did not follow this model, the inference about the nature of adsorption process seemed not to be reliable.

3.4. Effect of Temperature: Feasibility of the Process. The effect of change in temperature on the Cd(II)-UMRS sorption
TABLE 4: Values of thermodynamic parameters for Cd(II)-UMRS system.

\begin{tabular}{lccc}
\hline $\begin{array}{l}\text { Temperature } \\
(\mathrm{K})\end{array}$ & $\begin{array}{c}\Delta G^{\circ} \\
\left.(\mathrm{kJ} \mathrm{mol})^{-1}\right)\end{array}$ & $\begin{array}{c}\Delta H^{\circ} \\
\left(\mathrm{kJ} \mathrm{mol}^{-1}\right)\end{array}$ & $\begin{array}{c}\Delta S^{\circ} \\
\left(\mathrm{J} \mathrm{K}^{-1} \mathrm{~mol}^{-1}\right)\end{array}$ \\
\hline 293.16 & -1126.58 & 117.81 & 409.08 \\
303.16 & -7979.85 & & \\
313.16 & -9308.26 & & \\
\hline
\end{tabular}

system was studied to resolve the thermodynamic parameters and to investigate the nature/feasibility of the process. It was observed that the sorption capacity increased with increase in temperature. The $q_{e}$ values increased during the studied temperature range (293-313 K) from 1.9175 to $3.0400 \mathrm{mg} \mathrm{g}^{-1}$ of UMRS (figure not shown). This indicated that the sorption of Cd(II) by UMRS was an endothermic process and that UMRS could be effectively used for the biosorptive removal of $\mathrm{Cd}(\mathrm{II})$ ions from aqueous solutions at relatively higher temperatures.

The experimental data were used to determine the thermodynamic parameters like changes in standard free energy $\left(\Delta G^{\circ}\right)$, enthalpy $\left(\Delta H^{\circ}\right)$, and entropy $\left(\Delta S^{\circ}\right)$ using the following equations:

$$
\begin{aligned}
\Delta G^{\circ} & =-R T \ln K_{D}, \\
\Delta G^{\circ} & =\Delta H^{\circ}-T \Delta S^{\circ},
\end{aligned}
$$

where $T$ is the absolute temperature $(\mathrm{K})$ and $K_{D}\left[\left(C_{0}-\right.\right.$ $\left.\left.C_{e}\right) / C_{e}\right]$ is the distribution coefficient.

The thermodynamic parameters given in Table 4 were determined from the plot of $\Delta G^{\circ}$ versus $T$ (Figure 5(a)). The negative values of $\Delta G^{\circ}$ at the studied temperature range indicated that the sorption of $\mathrm{Cd}(\mathrm{II})$ by UMRS was thermodynamically feasible and spontaneous. The decrease in the value of $\Delta G^{\circ}$ with temperature further showed the increase in feasibility of sorption at elevated temperatures. In other words, the sorption was endothermic in nature. The positive value of $\Delta H^{\circ}$ also supported this statement. The positive value of $\Delta S^{\circ}$ showed the increased randomness at the solid-solution interface during the sorption of metal ions, and it also reflected the affinity of UMRS for metal ions [41].

3.4.1. Activation Energy. Activation energy $\left(E_{a}\right)$ is an important parameter related to the strength and type of forces present between $\mathrm{Cd}(\mathrm{II})$ ions and UMRS. It was determined using the following linear Arrhenius equation [26]:

$$
\ln k_{2}=\ln A_{1}-\frac{E_{a}}{R T},
$$

where $k_{2}$ is known as the pseudo-second-order rate constant, $A_{1}$ is the Arrhenius constant, $E_{a}$ refers to energy of activation $\left(\mathrm{kJ} \mathrm{mol}{ }^{-1}\right), R$ is the ideal gas constant $\left(8.3134 \mathrm{~J} \mathrm{~mol}^{-1} \mathrm{~K}^{-1}\right)$, and $T$ is the temperature of the medium (K). A graph was plotted between $\ln k_{2}$ and $1 / T$. The values of energy of activation $\left(E_{a}\right)$ and Arrhenius contact $(A)$ were determined from 


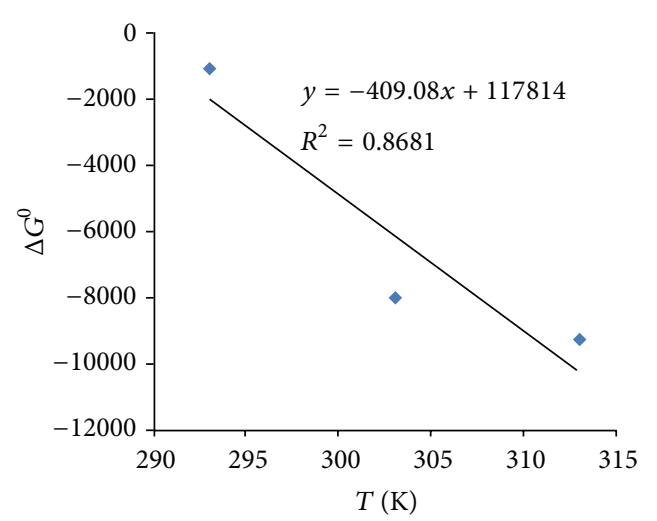

(a)

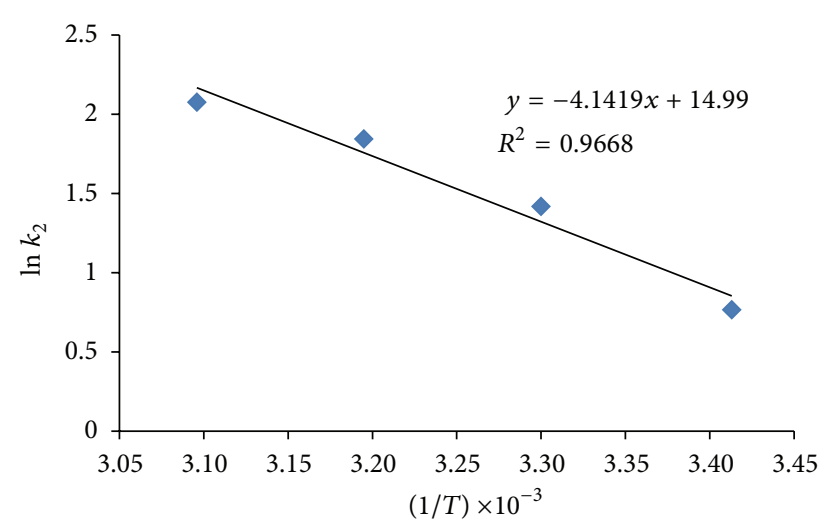

(b)

FIgURE 5: (a) Thermodynamic modeling and (b) activation energy for the Cd(II) onto UMRS under optimum conditions.

the slope and intercept of the linear plot (Figure 5(b)). The $E_{a}$ value is found to be $34.42 \mathrm{~kJ} \mathrm{~mol}^{-1}$ indicating relatively weak forces to be involved in the biosorption process indicating the process to be physisorption.

3.5. Dose of UMRS. Dose of biomass is very important in determining the minimum amount required to treat a solution of given metal concentration. By increasing the amount of biomass, the number of available sites is also increased. The effect of dose of UMRS on percentage adsorption of $\mathrm{Cd}(\mathrm{II})$ ions was studied at an initial concentration of $50 \mathrm{mg} \mathrm{L}^{-1}$ by varying the amount from 0.2 to $1.4 \mathrm{~g}$ per $50 \mathrm{~mL}$ of $\mathrm{Cd}(\mathrm{II})$ solution. At optimum conditions, it was observed that by increasing the dose, the $q_{e}$ values also increased initially (figure not shown). After increasing the dose to $0.8 \mathrm{~g}$ per $50 \mathrm{~mL}$, the $q_{e}$ values decreased. The increase in $q_{e}$ can be attributed to the increase in the number of sites at UMRS. After maximum Cd(II) ions are attached at $0.8 \mathrm{~g}$ per $50 \mathrm{~mL}$, the increase in dose caused $q_{e}$ values to decrease. As $q_{e}$ values are calculated by dividing $C_{0}-C_{e}$ by mass of UMRS, so $q_{e}$ values decreased, although the removal $(R \%)$ increased. In addition, the decrease may be attributed to overlapping or aggregating of sites at UMRS resulting in decrease in total UMRS surface area available to Cd(II) ions. It can be inferred that $0.8 \mathrm{~g}$ of UMRS was sufficient to detoxify a solution containing $50 \mathrm{mg} \mathrm{Cd(II)} \mathrm{per} \mathrm{liter} \mathrm{of} \mathrm{solution.}$

3.6. Effect of Agitation Speed. Agitation speed is considered as one of the important process parameter which significantly affects the biosorption of Cd(II) onto UMRS. When UMRS is made to come into contact with $\mathrm{Cd}(\mathrm{II})$ bearing solution, the metal ions present close to it are readily attached. This generates a concentration gradient in the metal-biomass system. By agitating the metal-biomass system, the effect of such a concentration gradient is minimized, and the metal ions present in the solution are distributed evenly in the solution. Moreover, agitation distributes the biomass in the solution more evenly as compared to the situation when there is no agitation. On the other hand, agitation also causes desorption of the loosely bound metal ions from the surface of biomass. So an optimum speed of agitation is very much
TABLE 5: Characterization of UMRS.

\begin{tabular}{llc}
\hline & $\mathrm{C}(\%)$ & 49.98 \\
Elemental analysis & $\mathrm{H}(\%)$ & 6.86 \\
& $\mathrm{~N}(\%)$ & 7.08 \\
& $\mathrm{~S}(\%)$ & 0.82 \\
\hline \multirow{2}{*}{ FTIR analysis $\left(\mathrm{cm}^{-1}\right)$} & $3819.1 ; 3287.4 ; 2349.4 ; 1697.9 ; 1429.1 ; 1048.8 ;$ \\
& $768.5 ; 674.9$ & \\
\hline
\end{tabular}

essential for the efficient removal of metal ions from the solution.

The effect of agitation speed was monitored on the biosorption of Cd(II) by UMRS by varying the speed from 50 to $250 \mathrm{rpm}$ at optimum conditions (figure not shown). As the agitation speed was increased, $q_{e}$ value initially increased and reached a maximum at $125 \mathrm{rpm}$. After that, the increase in speed caused the biosorption of $\mathrm{Cd}(\mathrm{II})$ to decrease. If agitation speed is low UMRS accumulates in the solution instead of distributing in the solution. Various active sites are buried forming layers of UMRS on one another and thus do not participate in the biosorption process. So sorption occurs only at the top surface layer resulting in lesser $q_{e}$ values. On the other hand, at higher agitation speeds, desorption of bound Cd(II) ions increases, and the sorption-desorption equilibrium is shifted towards the desorption and the $q_{e}$ values decreases. On the basis of the previous discussion, an agitation speed of $125 \mathrm{rpm}$ was selected as an optimum speed for the Cd(II) biosorption by UMRS.

3.7. Characterization of UMRS. Elemental analysis and FTIR analysis were carried out using powdered, dried urea modified rice straw. The characterization revealed the information regarding adsorption sites in terms of functional groups. Simple rice straw consists of cellulose (32.24\%), hemicellulose (21.34\%), lignin (21.44\%), and mineral ash (15.05\%) [37]. The elemental analysis of urea modified rice straw showed relatively higher percentage of carbon, hydrogen, oxygen, and nitrogen (Table 5). The percentage of nitrogen, that is, 7.08\% is of special concern. The high content of nitrogen in UMRS pointed to the fact that after modification urea was attached to already present functional groups present in the rice straw. 


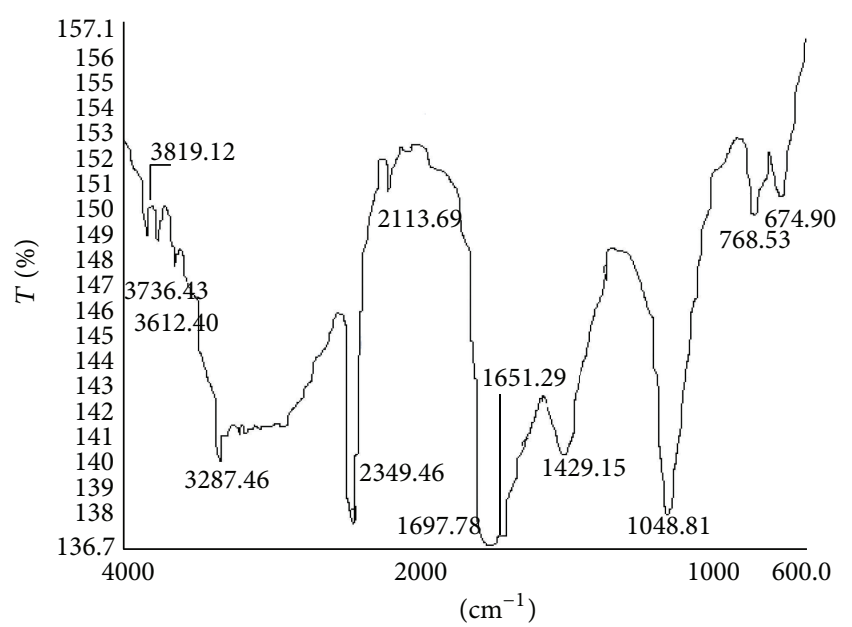

FIGURE 6: FTIR of UMRS.

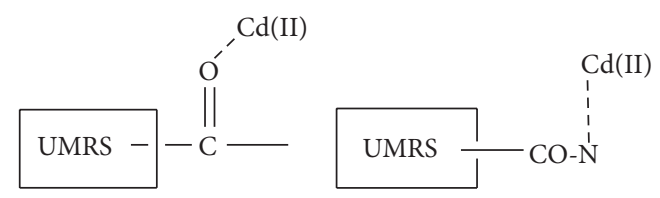

FIGURE 7: Proposed attachment/binding sites of Cd(II) ions onto the UMRS biosorbent $\left(C_{0}=50 \mathrm{mg} / \mathrm{L}\right)$.

The FTIR is an important technique to identify potential functional groups that may participate in the binding of metal ions. The characteristic FTIR bands for UMRS (Figure 6) are given in Table 5. A number of peaks/bands can be recognized. The broadband in $3000-2800 \mathrm{~cm}^{-1}$ region is mainly due to $\mathrm{O}-\mathrm{H}$ stretching vibrations. The $\mathrm{N}-\mathrm{H}$ and $\mathrm{C}-\mathrm{H}$ bands also arise in this region, and these are buried under the broad $\mathrm{O}-\mathrm{H}$ band, although some very weak peaks may be seen. The presence of $\mathrm{C} \equiv \mathrm{C}$ and $\mathrm{C} \equiv \mathrm{N}$ can be observed by the peak around 2300 and $2100 \mathrm{~cm}^{-1}$. The sharp peak at $1697.78 \mathrm{~cm}^{-1}$ may be attributed to the carbonyl groups of aldehydes and ketones present in the large molecules in the cell wall of the biosorbent material. The presence of a band near $1650 \mathrm{~cm}^{-1}$ pointed to the presence of amide group. The $\mathrm{C}-\mathrm{H}$ bending and $\mathrm{C}-\mathrm{O}-\mathrm{C}$ stretching may be observed around 1430 and $1050 \mathrm{~cm}^{-1}$, respectively. Thus it can be inferred that UMRS is polyfunctional in nature. Cd(II) has been found to attach with the oxygen and nitrogen containing functional groups present in the biomass. As UMRS is rich in these functional groups, it can be used for the binding of $\mathrm{Cd}(\mathrm{II})$ ions in a significant amount. The binding may be proposed as shown in Figure 7.

\section{Conclusion}

The present study was based on the efficiency evaluation of a low cost urea modified agricultural waste material for the adsorption of $\mathrm{Cd}(\mathrm{II})$ ions from water. Characterization of the modified adsorbent using FTIR and elemental analysis affirmed the urea modification by showing peaks of amide group and a high nitrogen content, respectively. Process parameters were optimized for equilibrium study. According to the results maximum adsorption was observed when $0.8 \mathrm{~g}$ per $50 \mathrm{~mL}$ of modified adsorbent remained in contact with $50 \mathrm{mg} \mathrm{L}^{-1} \mathrm{Cd}(\mathrm{II})$ ions solution for $10 \mathrm{~min}$ at $\mathrm{pH} 6$ keeping agitation speed $125 \mathrm{rpm}$ at temperature $303 \mathrm{~K}$. Five different adsorption isotherms (Langmuir, Freundlich, Temkin, Harkin-Jura, and Dubinin-Radushkevich) were used for the adsorption modeling and equilibrium study. It was observed that Langmuir model better fitted to the equilibrium data, the maximum uptake capacity was found to be $20.70 \mathrm{mg} \mathrm{g}^{-1}$, and $R_{L}$ factor showed the favorability of the adsorption process. Temkin isotherm indicated physisorption to be the operating process for the uptake of Cd(II) ions by urea modified adsorbent due to weak interactions and lower heat of adsorption. $E$ value obtained from D-R model corroborated this statement. Kinetics of the process was investigated by six different kinetic models. The kinetic study indicated that adsorption mechanism obeyed pseudo-second-order kinetic model. Intraparticle diffusion model proposed boundary layer diffusion as rate determining step for the process. Thermodynamic parameters such as $\Delta G^{\circ}, \Delta H^{\circ}$, and $\Delta S^{\circ}$ showed the exothermic nature of the process along with its feasibility and spontaneity. Increase in entropy $\Delta S^{\circ}$ indicated the favorability of adsorption of $\mathrm{Cd}(\mathrm{II})$ ions by urea modified rice straw affirming its effectiveness and application for waste water treatment. Thus urea modified rice straw can be considered a cost effective and benign adsorbent for the removal of heavy metal ions such as Cd(II) ions from aqueous solutions.

\section{References}

[1] K. E. Giller, E. Witter, and S. P. Mcgrath, "Toxicity of heavy metals to microorganisms and microbial processes in agricultural soils: a review," Soil Biology and Biochemistry, vol. 30, no. 10-11, pp. 1389-1414, 1998.

[2] M. P. Waalkes, "Cadmium carcinogenesis," Mutation Research, vol. 533, no. 1-2, pp. 107-120, 2003.

[3] S. D. Faust and O. M. Aly, Adsorption Process for Water Treatment, Butterworths Publishers, Stoneham, Mass, USA, 1987.

[4] S. S. Ahluwalia and D. Goyal, "Microbial and plant derived biomass for removal of heavy metals from wastewater," Bioresource Technology, vol. 98, no. 12, pp. 2243-2257, 2007.

[5] S. Doyurum and A. Çelik, "Pb(II) and Cd(II) removal from aqueous solutions by olive cake," Journal of Hazardous Materials, vol. 138, no. 1, pp. 22-28, 2006.

[6] K. S. Low, C. K. Lee, and S. C. Liew, "Sorption of cadmium and lead from aqueous solutions by spent grain," Process Biochemistry, vol. 36, no. 1-2, pp. 59-64, 2000.

[7] Y. C. Sharma, "Economic treatment of cadmium(II)-rich hazardous waste by indigenous material," Journal of Colloid And Interface Science, vol. 173, no. 1, pp. 66-70, 1995.

[8] K. K. Singh, A. K. Singh, and S. H. Hasan, "Low cost bio-sorbent "wheat bran" for the removal of cadmium from wastewater: kinetic and equilibrium studies," Bioresource Technology, vol. 97, no. 8, pp. 994-1001, 2006.

[9] S. Deng and Y. P. Ting, "Polyethylenimine-modified fungal biomass as a high-capacity biosorbent for $\mathrm{Cr}(\mathrm{VI})$ anions: sorption capacity and uptake mechanisms," Environmental Science and Technology, vol. 39, no. 21, pp. 8490-8496, 2005. 
[10] A. J. Francis, C. J. Dodge, J. B. Gillow, and H. W. Papenguth, "Biotransformation of uranium compounds in high ionic strength brine by a halophilic bacterium under denitrifying conditions," Environmental Science and Technology, vol. 34, no. 11, pp. 2311-2317, 2000.

[11] S. Lin and G. D. Rayson, "Impact of surface modification on binding affinity distributions of Datura innoxia biomass to metal ions," Environmental Science and Technology, vol. 32, no. 10, pp. 1488-1493, 1998.

[12] J. Wang, "Biosorption of copper(II) by chemically modified biomass of Saccharomyces cerevisiae," Process Biochemistry, vol. 37, no. 8, pp. 847-850, 2002.

[13] J. Wang and C. Chen, "Biosorption of heavy metals by Saccharomyces cerevisiae: a review," Biotechnology Advances, vol. 24, no. 5, pp. 427-451, 2006.

[14] E. L. Errasquín and C. Vázquez, "Tolerance and uptake of heavy metals by Trichoderma atroviride isolated from sludge," Chemosphere, vol. 50, no. 1, pp. 137-143, 2003.

[15] U. S. Orlando, A. U. Baes, W. Nishijima, and M. Okada, "Preparation of chelating agents from sugarcane bagasse by microwave radiation as an alternative ecologically benign procedure," Green Chemistry, vol. 4, no. 6, pp. 555-557, 2002.

[16] U. Farooq, J. A. Kozinski, M. A. Khan, and M. Athar, "Biosorption of heavy metal ions using wheat based biosorbents-a review of the recent literature," Bioresource Technology, vol. 101, no. 14, pp. 5043-5053, 2010.

[17] F. A. Chandio, J. Changying, A. A. Tagar, I. A. Mari, T. Guangzhao, and D. M. Cuong, "Comparison of mechanical properties of wheat and rice straw influenced by loading rates," African Journal of Biotechnology, vol. 12, pp. 1068-1077, 2013.

[18] U. Farooq Umar, M. A. Khan, M. Athar, and J. A. Kozinski, "Effect of modification of environmentally friendly biosorbent wheat (Triticum aestivum) on the biosorptive removal of cadmium(II) ions from aqueous solution," Chemical Engineering Journal, vol. 171, no. 2, pp. 400-410, 2011.

[19] H. Eccles and S. Hunt, Immobilization of Ions By Biosorption, Ellis Horwood Limited, Chichester, UK, 1986.

[20] O. M. M. Freitas, R. J. E. Martins, C. M. Delerue-Matos, and R. A. R. Boaventura, "Removal of $\mathrm{Cd}(\mathrm{II}), \mathrm{Zn}(\mathrm{II})$ and $\mathrm{Pb}(\mathrm{II})$ from aqueous solutions by brown marine macro algae: kinetic modelling," Journal of Hazardous Materials, vol. 153, no. 1-2, pp. 493-501, 2008.

[21] G. Tan and D. Xiao, "Adsorption of cadmium ion from aqueous solution by ground wheat stems," Journal of Hazardous Materials, vol. 164, no. 2-3, pp. 1359-1363, 2009.

[22] L. Nouri, I. Ghodbane, O. Hamdaoui, and M. Chiha, "Batch sorption dynamics and equilibrium for the removal of cadmium ions from aqueous phase using wheat bran," Journal of Hazardous Materials, vol. 149, no. 1, pp. 115-125, 2007.

[23] J. Zeldowitwch, "Urben den mechanismus der katalytischen oxydation von $\mathrm{CO}$ and $\mathrm{MnO}_{2}$," Acta Physicochimica USSR, vol. 1, pp. 449-464, 1934.

[24] S. Lagergren, "Zur theorie der sogenannten adsortion geloster stoffe, Kungliga Svenska Vetenskapsakademiens," Handlingar, Band, vol. 24, no. 1, pp. 1-34, 1898.

[25] Y.-S. Ho, "Citation review of Lagergren kinetic rate equation on adsorption reactions," Scientometrics, vol. 59, no. 1, pp. 171-177, 2004.

[26] Y. S. Ho and G. McKay, "Sorption of dye from aqueous solution by peat," Chemical Engineering Journal, vol. 70, no. 2, pp. 115124, 1998.
[27] Y.-S. Ho, "Review of second-order models for adsorption systems," Journal of Hazardous Materials, vol. 136, no. 3, pp. 681689, 2006.

[28] C. W. Cheung, J. F. Porter, and G. McKay, "Elovich equation and modified second-order equation for sorption of cadmium ions onto bone char," Journal of Chemical Technology and Biotechnology, vol. 75, no. 11, pp. 963-970, 2000.

[29] C. W. Cheung, J. F. Porter, and G. Mckay, "Sorption kinetic analysis for the removal of cadmium ions from effluents using bone char," Water Research, vol. 35, no. 3, pp. 605-612, 2001.

[30] W. J. Weber and J. C. Morris, "Advances in water pollution research: removal of biologically resistant pollutant from waste water by adsorption," in International Conference on Water Pollution Syposium, pp. 231-236, Pergamon Press, 1962.

[31] I. Langmuir, "The adsorption of gases on plane surfaces of glass, mica and platinum," The Journal of the American Chemical Society, vol. 40, no. 9, pp. 1361-1403, 1918.

[32] H. M. F. Freundlich, "Uber die adsorptio nin losungen," Zeitschrift Fur Physikalische Chemie A, vol. 57, pp. 385-470, 1906.

[33] M. Temkin, "Die gas adsorption und der nernstsche warmesatz," Acta Physicochimica USSR, vol. 1, pp. 36-52, 1934.

[34] W. D. Harkins and G. Jura, "Surfaces of solids. XIII. A vapor adsorption method for the determination of the area of a solid without the assumption of a molecular area, and the areas occupied by nitrogen and other molecules on the surface of a solid," Journal of the American Chemical Society, vol. 66, no. 8, pp. 1366-1373, 1944.

[35] M. M. Dubinin and L. V. Radushkevich, "On the characteristic curve equation for active charcoals," Doklay Akademii Nauk, vol. 15, pp. 327-329, 1947.

[36] K. R. Hall, L. C. Eagleton, A. Acrivos, and T. Vermeulen, "Pore- and solid-diffusion kinetics in fixed-bed adsorption under constant-pattern conditions," Industrial and Engineering Chemistry Fundamentals, vol. 5, no. 2, pp. 212-223, 1966.

[37] I. A. Rahman and J. Ismail, "Preparation and characterization of a spherical gel from a low-cost material," Journal of Materials Chemistry, vol. 3, no. 9, pp. 931-934, 1993.

[38] J. Anwar, U. Shafique, W.-U. Waheed-Uz-Zaman, M. Salman, A. Dar, and S. Anwar, "Removal of $\mathrm{Pb}$ (II) and $\mathrm{Cd}(\mathrm{II})$ from water by adsorption on peels of banana," Bioresource Technology, vol. 101, no. 6, pp. 1752-1755, 2010.

[39] C. Theivarasu, S. Mylsamy, and N. Sivakumar, "Removal of malachite green from aqueous solution by activated carbon developed from cocoa (Theobroma cacao) shell: kinetic and equilibrium studies," Oriental Journal of Chemistry, vol. 27, no. 3, pp. 1083-1091, 2011.

[40] V. B. H. Dang, H. D. Doan, T. Dang-Vu, and A. Lohi, "Equilibrium and kinetics of biosorption of cadmium(II) and copper(II) ions by wheat straw," Bioresource Technology, vol. 100, no. 1, pp. 211-219, 2009.

[41] M. Iqbal and R. G. J. Edyvean, "Alginate coated loofa sponge discs for the removal of cadmium from aqueous solutions," Biotechnology Letters, vol. 26, no. 2, pp. 165-169, 2004.

[42] E. W. Shin and R. M. Rowell, "Cadmium ion sorption onto lignocellulosic biosorbent modified by sulfonation: the origin of sorption capacity improvement," Chemosphere, vol. 60, no. 8, pp. 1054-1061, 2005.

[43] N. Jamil, M. A. Munawar, S. Babar, and S. T. Muntaha, "Biosorption of $\mathrm{Hg}$ (II) and Cd (II) from waste water by using Zea Mays waste," Journal of the Chemical Society of Pakistan, vol. 31, no. 3, pp. 362-369, 2009. 
[44] Y.-S. Ho and A. E. Ofomaja, "Biosorption thermodynamics of cadmium on coconut copra meal as biosorbent," Biochemical Engineering Journal, vol. 30, no. 2, pp. 117-123, 2006.

[45] M. O. Omorogie, J. O. Babalola, E. I. Unuabonah, and J. R. Gong, "Kinetics and thermodynamics of heavy metal ions sequestration onto novel Nauclea diderrichii seed biomass," Bioresource Technology, vol. 118, pp. 576-579, 2012.

[46] H. S. Ibrahim, N. S. Ammar, M. Soylak, and M. Ibrahim, "Removal of $\mathrm{Cd}(\mathrm{II})$ and $\mathrm{Pb}$ (II) from aqueous solution using dried water hyacinth as a biosorbent," Spectrochimica Acta Part A, vol. 96, pp. 413-420, 2012.

[47] A. Saeed, M. W. Akhter, and M. Iqbal, "Removal and recovery of heavy metals from aqueous solution using papaya wood as a new biosorbent," Separation and Purification Technology, vol. 45, no. 1, pp. 25-31, 2005.

[48] J.-M. Luo, X. Xiao, and S.-L. Luo, "Biosorption of cadmium(II) from aqueous solutions by industrial fungus Rhizopus cohnii," Transactions of Nonferrous Metals Society of China, vol. 20, no. 6, pp. 1104-1111, 2010. 

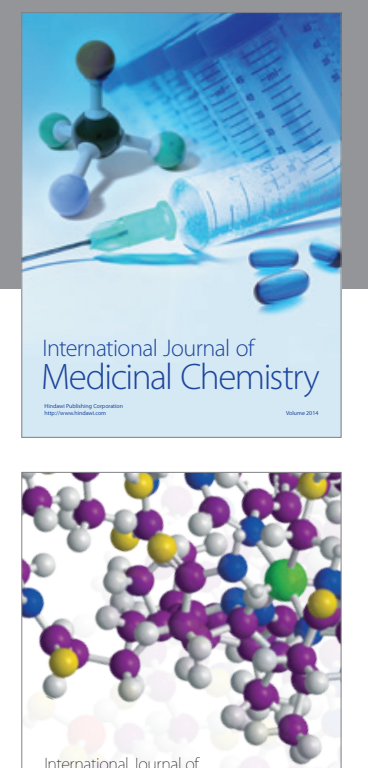

\section{Carbohydrate} Chemistry

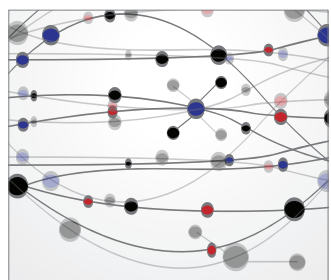

The Scientific World Journal
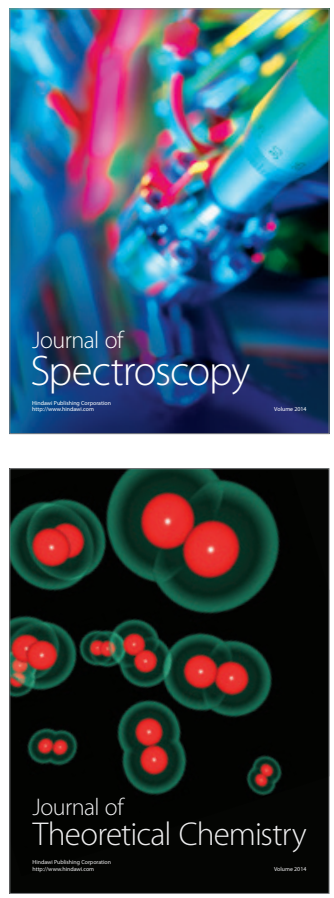
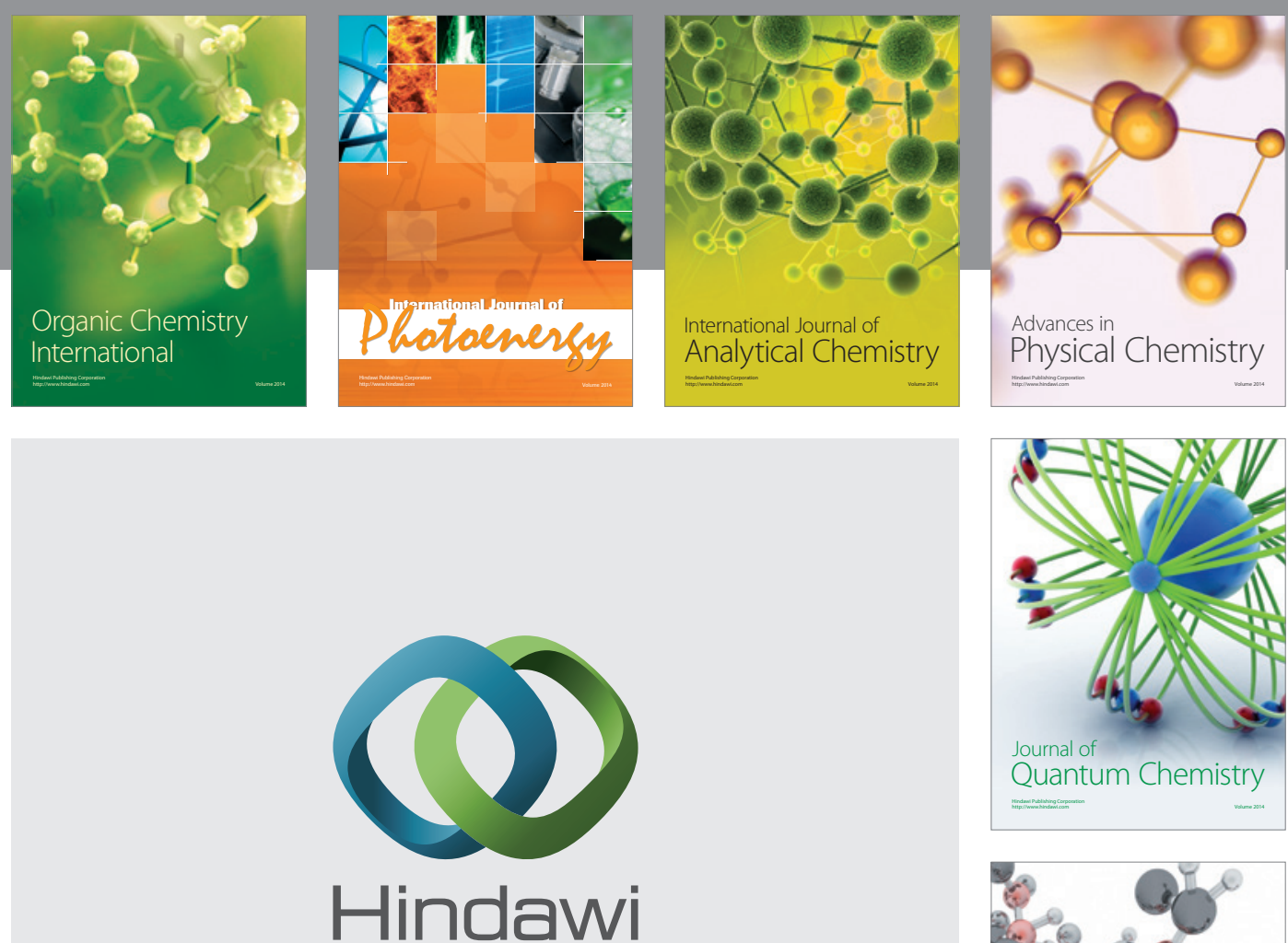

Submit your manuscripts at

http://www.hindawi.com

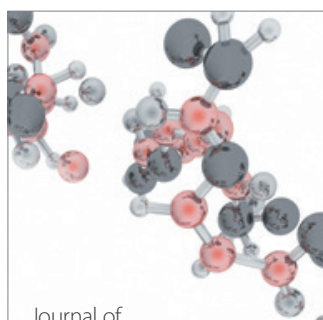

Analytical Methods

in Chemistry

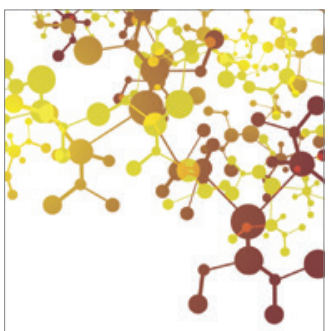

Journal of

Applied Chemistry

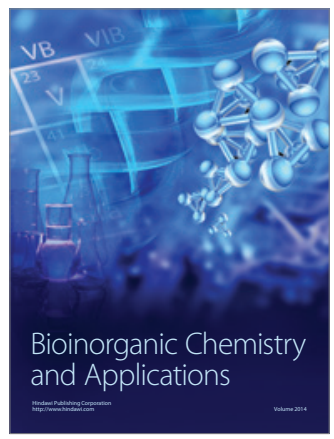

Inorganic Chemistry
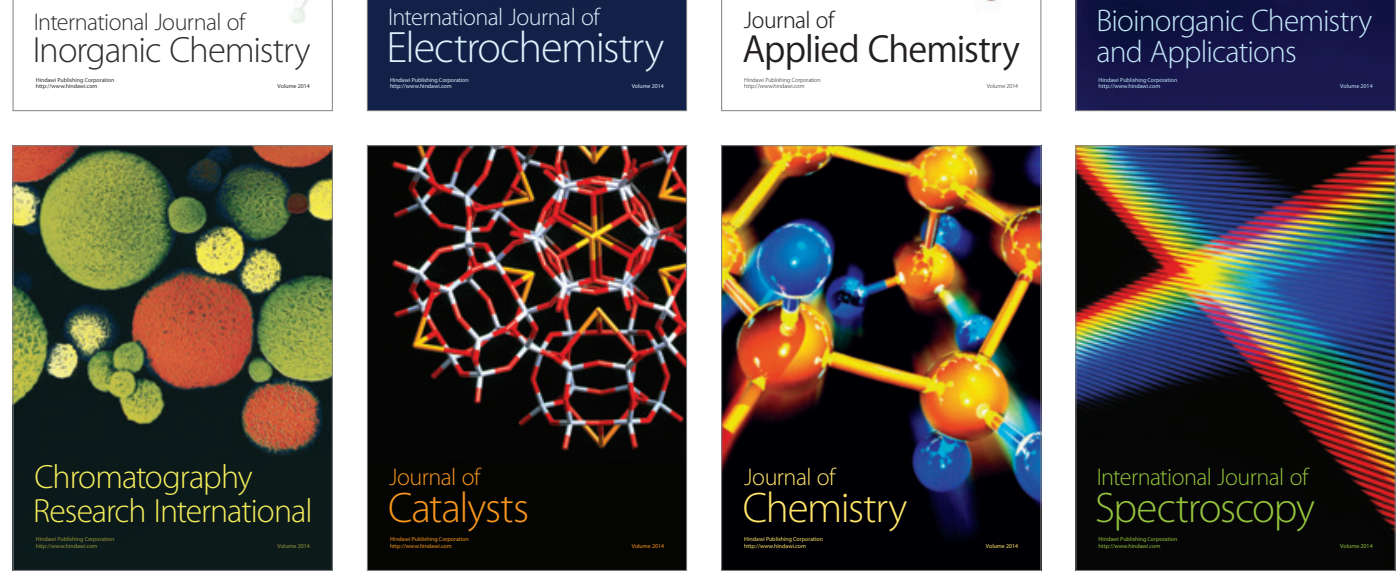